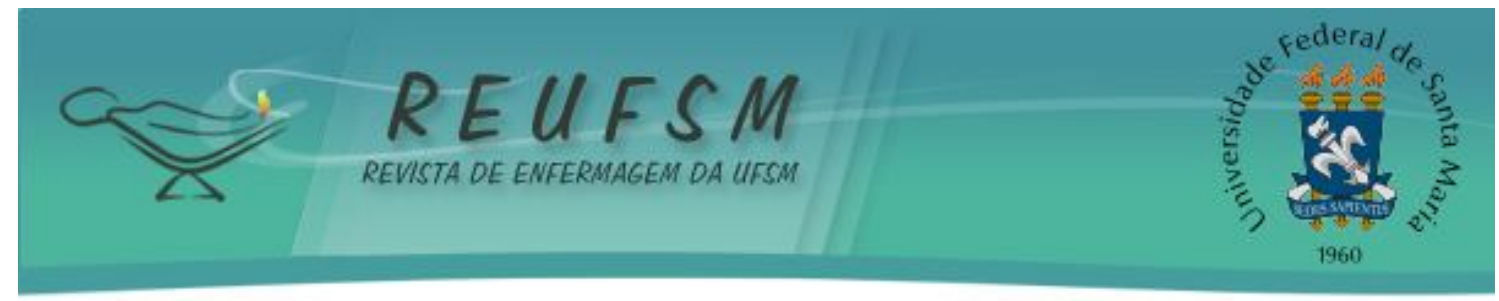

RESUMO

\title{
TRABALHO EDUCATIVO DO ENFERMEIRO NA ESTRATÉGIA SAÚDE DA FAMÍLIA NA 10a REGIONAL DE SAÚDE DO PARANÁ
}

\author{
NURSE'S EDUCATIONAL WORK IN THE FAMILY HEALTH STRATEGY IN THE 10TH \\ REGIONAL HEALTH OF PARANÁ
}

\section{TRABAJ $O$ EDUCATIVO DEL ENFERMERO EN LA EST RATEGIA SALUD DE LA FAMILIA EN LA 10a REGIONAL DE SALUD DE PARANÁ}

\author{
Simone Roecker ${ }^{1}$ \\ Sonia Silva Marcon ${ }^{2}$
}

\begin{abstract}
RESUMO: O objetivo do estudo foi compreender a percepção dos enfermeiros sobre 0 trabalho educativo desenvolvido na Estratégia Saúde da Família (ESF), no âmbito da 10 a Regional de Saúde do Estado do Paraná. Trata-se de um estudo descritivo-exploratório, com abordagem qualitativa aprovada pelo Comitê de Ética da Universidade Estadual de Maringá/ PR (659/2009). Os dados foram coletados junto a 20 enfermeiros que atuam na ESF por meio de entrevistas semiestruturadas, durante o mês de abril de 2010 e submetidos à análise de conteúdo categorial (Bardin). Os resultados demonstram que os enfermeiros compreendem o conceito de educação em saúde e reconhecem a sua relevância, especialmente no tocante à atenção primária à saúde, contudo, as ações educativas por eles realizadas ainda estão aquém do preconizado pela ESF e, em sua maioria, atreladas ao modelo tradicional de educação em saúde. São enfrentados diversos obstáculos na realização da prática educativa devido ao desconhecimento das tendências pedagógicas e da falta de sistematização das ações que guiam o fazer educativo dos enfermeiros. Além desses obstáculos, os enfermeiros enfrentam diversas dificuldades no desenvolvimento da educação em saúde referente aos usuários, aos membros da equipe multiprofissional, aos gestores e à insuficiência de recursos físicos, materiais e financeiros. Nesse sentido, ressalta-se a necessidade de se esclarecer melhor os objetivos da ESF relacionados com a educação em saúde aos profissionais atuantes neste modelo assistencial, estabelecendo um processo de capacitação e de educação permanente, além de desenvolver meios de sistematizar a educação em saúde desde a formação profissional. Desse modo, a educação em saúde não deve ser considerada apenas como mais uma atividade a ser realizada na ESF, mas sim, uma prática que alicerça e reorienta toda a atenção primária, a fim de promover a saúde dos indivíduos, das famílias e da comunidade.
\end{abstract}

DESCRITORES: Enfermagem em saúde pública; Papel do profissional de enfermagem; Saúde da família; Atenção primária à saúde; Educação em saúde.

ABSTRACT: The aim of this study was to understand the nurses' perception about the educational work developed in the Family Health Strategy (FHS), in the scope of the 10th Regional Health of the State of Paraná. This is a descriptive exploratory study, with qualitative research approved by the Ethics Committee of the University of Maringá (659/2009). The data were collected from 20 nurses that work in the FHS through semistructured interviews, during the month of April 2010 and submitted to the categorical content analysis (Bardin). The results show that nurses understand the concept of health education and recognize its relevance, especially concerning to primary health care, however, the educational actions achieved by them are still below the recommended by

\footnotetext{
${ }^{1}$ Enfermeira. Mestre em Enfermagem pela Universidade Estadual de Maringá/ PR. Email: moneroecker@hotmail.com.

2 Enfermeira. Doutora em Filosofia da Enfermagem. Docente da pós-graduação em Enfermagem da Universidade Estadual de Maringá/ Paraná. Email: soniasilva.marcon@gmail.com.
} 


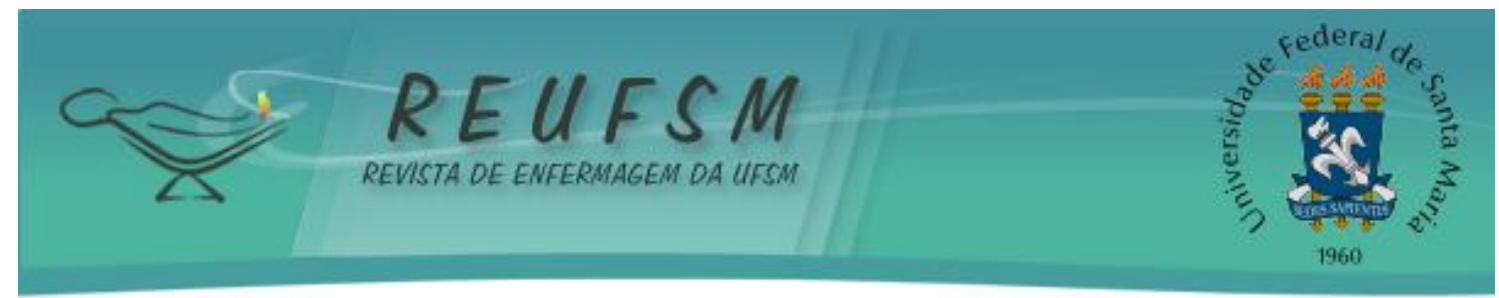

the FHS and, mostly, tied to the traditional model of health education. They are faced several obstacles in the realization of educational practice due to the unawareness of pedagogical trends and lack of systematization on the actions that lead the make educative of nurses. Besides these obstacles, the nurses face several difficulties in the health education development referent to users, to members of the multi-professional team, to managers and to insufficiency of physical, material and financial resources. Therefore, it was emphasized the need to clarify better the objectives of the FHS related with the health education for professionals working in this care model, establishing a process of training and continuing education, besides develop means to systematize the health education since the professional formation. Thus, health education must not be considerate just as another activity to be achieved at FHS, but as a practice that sustain and reorients all primary care, aim to promote the health of individuals, families and community.

DESCRIPTORS: Public health nursing; Nurse's role; Family health; Primary health care; Health education.

RESUMEN: El objetivo del estudio fue comprender la percepción de los enfermeros sobre el trabajo educativo desarrollado en la Estrategia Salud de la Familia (ESF), en el ámbito de la 10 a Regional de Salud del Estado de Paraná. Se trata de un estudio descriptivoexploratorio, con abordaje cualitativo, aprobado por el Comité de Ética de la Universidad Estadual de Maringá (659/2009). Los datos fueron recogidos por medio de entrevistas semiestructuradas con 20 enfermeros que actúan en la ESF, durante el mes de abril de 2010, y sometidos al análisis de contenido categorial (Bardin). Los resultados demuestran que los enfermeros comprenden el concepto de educación en salud y reconocen su relevancia, especialmente en lo que respecta a la atención primaria a la salud, con todo, las acciones educativas por ellos realizadas aún están por debajo del preconizado por la ESF y, en su mayoría, mezcladas al modelo tradicional de educación en salud. Se enfrentan diversos obstáculos en la realización de la práctica educativa debido al desconocimiento de las tendencias pedagógicas y de la falta de sistematización de las acciones que guían el hacer educativo de los enfermeros. Además de esos obstáculos, los enfermeros enfrentan diversas dificultades en el desarrollo de la educación en salud referente a los usuarios, a los miembros del equipo multiprofesional, a los gestores y a la insuficiencia de recursos físicos, materiales y financieros. En ese sentido, resaltamos la necesidad de que se aclaren mejor los objetivos de la ESF relacionados con la educación en salud a los profesionales actuantes en este modelo asistencial, estableciendo un proceso de capacitación y de educación permanente, además de desarrollar medios de sistematizar la educación en salud desde la formación profesional. De ese modo, la educación en salud no debe considerarse apenas como una actividad más a ser realizada en la ESF, sino una práctica que fundamenta y reorienta toda la atención primaria, a fin de promover la salud de los individuos, de las familias y de la comunidad.

DESCRIPTORES: Enfermería en salud pública; Rol de la enfermera; Salud de la familia; Atención primaria de salud; Educación en salud.

Data de recebimento: 02/02/ 2011

Data de aceite: 06/04/2011

Contato com autora responsável: Simone Roecker.

Endereço: Rua Ranulfo Cardoso, n 42, Bairro Parque Verde, Cafelândia, Paraná. CEP: 85415-000. E-mail: moneroecker@hotmail.com. 